\title{
RELATIONS AMONG STUDENTS - SCHOOL CLIMATE FACTORS ${ }^{1}$
}

\author{
Helena Grecmanová, Lucie Blaštíková
}

\begin{abstract}
The area of school climate has been a hot topic both in Czech and in international studies; it must be dealt with also with respect to the needs of practice, if relations among students are to be improved. The article discusses the climate of the senior elementary school $\left(6^{\text {th }}-9^{\text {th }}\right.$ year), primarily in connection with its essential factors, i.e. students. The text presents theoretical foundations of school climate from selected national and international authors. Basic research tools that served as source of inspiration for the actual research are stated; the research is described in the next part of the article and it is based on the project implemented in 2015. Our goal consists in presenting the results of the research aimed at revealing the relations among students in selected elementary schools from the perspective of students, teachers and parents. The method of questionnaire research was used. Weak, but significant correlations among important areas of school life were revealed.
\end{abstract}

\section{Keywords}

school climate, elementary school, relations, students, research

Studies of climate have been used to describe school for more than fifty years, with an intermission in the 1970s when approaches observing the school culture were preferred. Recently, the interest in researching the school climate has been increasing again (Ježek, 2003; Hanke, 2005; Benack, 2006; Petlák, 2006; Cassinerio \& Lane-Garon, 2006; Grecmanová, 2008; Cohen et al., 2009; Gavora \& Braunová, 2010; Cemalcilar, 2010; Ding, Liu, \& Berkowitz, 2011; Lašek, 2012; Urbánek \& Chvál, 2012; Popa, 2012; Grecmanová et al., 2013; Kantorová, 2015; Hosford, 2016). One of the motives may consist in the finding

\footnotetext{
1 The article describes some findings detected at implementing the internal project of the Faculty of Pedagogy of the Palacký University in Olomouc called School climate as influenced by the school prevention methodist and social educator at elementary school.
} 
that the climate influences not only our feelings, including satisfaction or dissatisfaction in the given environment, behaviour, etc., but it can intensively determine the students' performance too (Fend, 1977; Moos, 1979; Dreesmann, 1979, 1981, 1982, Anderson, 1982; Fischer, 2003; Seebauer, 2005; Janke, 2006). In 2013, a school climate study (Momma \& Anis-Ul Maque, 2014) was implemented to find out how the school climate influences the quality and efficiency of lessons. The analysis of the acquired data was carried out with the help of factor analysis, in order to create specific dimensions (focus on relations, support and obstacles in lessons). The students (and teachers) spend much time at school, and it is therefore not surprising that they wish to spend the time in peace and without stress, so that they can feel good and perform well. If there is an unfavourable climate at school, the students and the teachers may experience pressure and threat. Instead of concentrating on their work, they spend energy to ensure their own safety (Bessoth, 1989). However, studies in the area of perception of the school climate, implemented at present, in relation to standards supporting safe and prosocial behaviour, confirm differences in the perception of the actual feeling of safety (Hopson, Schiler, \& Lawson, 2014). The article aims at defining the school climate, presenting research approaches to the school climate, and describing the actual research of climate at some senior elementary schools with focus on the relations among students from the perspective of students, teachers and parents. The following research question has been formulated in this respect: how are relations among students in selected elementary schools assessed by students, teachers and parents? The research of the school climate was implemented in 2015 at four elementary schools in the Czech Republic, involved in the project (see footnote).

\section{School climate}

The school climate is a psychosocial phenomenon related to perception, experiencing and evaluation of the school environment by its participants, particularly teachers, students and parents (Grecmanová, 2008). Teachers, students and parents are influenced by persons (their characteristics, qualities, competences, etc.) they meet at school, communicating and establishing relations with them. The students' personal features can be observed as their individual characteristics or as the characteristics of their class (Janke, 2006). The relations among schoolmates are considered the most important "climate-forming" factors by Rosolová and Střelec (2003). The social dimension that daily influences peoples' experience is an important part of the school environment and climate. Therefore increased attention is paid to it in our study too. However, the school environment includes also the cultural dimension (e.g. curriculum, values, image, traditions) influencing the specific character of the school, and material dimension (school architecture, equipment, aesthetic arrangement) is not insignificant either.

With these factors, objects, phenomena, processes, etc. in the school environment, the students, teachers and parents contact each other more or less regularly, they interact with each other and filter the interaction subjectively in their experience. The impressions 
from the environment are influenced by inner subjective conditions, e.g. by values, experience, quality of perceptions, the percipient's expectations, etc. (Grecmanová, Geršicová, \& Muchacká, 2012) and by outer objective conditions concerning the school environment. The mood, feeling, experience, impression from (in) the school environment, described as its climate, have a long lasting character. If that condition is not fulfilled, it is not climate. Short lasting experiences in the school environment, related to a specific situation, are connected with the atmosphere. The school climate is shaped in the long term and it also changes in the long term. The changes in the school climate are challenging and everybody involved in shaping the climate should participate in them (Benack, 2006; Mareš, 2005).

The individual factors and components of the environment act upon the school climate not only on their own behalf but within a system in which they get into different variable relations. Foreign studies focused on the school climate can serve as an example: they perceived school as a complex in which all students and teachers participate in, experience and perceive the processes taking place at school. Also parents as indirect participants of the educational process were considered important climate factors. A study was focused on students with problematic school absences. A contribution to the students' truancy and high absence was assumed at the parents' side (Hendron \& Kearney, 2016). An Irish study, focused on perception of the school climate by teachers in relation to the efficiency of the inclusive practice points out how the whole process of inclusion affects individual climate factors, primarily the teachers who get into new and difficult conditions (Hosford, 2016).

The school climate includes the climate of the teaching staff, the climate of classes, the climate of lessons, the climate of communication, etc. All of them are specific phenomena influencing each other. Each of the above stated climate variants is, as Ježek (2003) says, an arbitrarily defined set of aspects of the school environment. That means that they, similarly to the school climate, are dependent, but always only on specific facts, phenomena and factors of the environment and on perceptions of a specific group of people acting at school. For example the class climate is related primarily to social and cultural dimension; it is experienced and reported by students. As Fend (1977) states, differences between classes are caused by mutual relations taking place in them. Therefore the climates of individual classes differ. But the class climates at a school can be considerably similar thanks to similar approaches and relations in the classes among the students and relations between the teacher and the students. Then we perceive a "unified spirit" at the school.

This text relies on the fact that each school has its specific climate. The type of the climate can be determined for each school. The following positive climatic types are mentioned in literature (Oswald, 1989): climate of school with educative target orientation, plurality, open and progressive climate with great interest in working tasks of the school and in human contacts, personality-oriented climate, with democratic direction, with life-oriented educational process. The favourable climate is usually identified in the environment of a school where teachers and students have an intimate relation full of confidence, 
the students cooperate, are ready to help each other, "everybody" fulfils the school obligations, etc. A considerably favourable climate is also identified in connection with so called progressive teachers who look with favour upon changes, are not conformist, criticize pressure on performance, have an optimistic view of human, require sense of belonging to the group, but also independence (Fend, 1977). According to German teachers, shaping of a favourable climate has the following important conditions: emotional harmony and sense of belonging to other teachers, success in the discipline and self-fulfilment, cooperation with colleagues and with students, satisfaction with the given situation (Schaffer, unpublished texts). A study mentioned by Stangl (1982) shows that the climate is positively influenced by favourable actions of the parents towards school. The favourable climate brings increasing parents' interest in school, improved cooperation between the parents and the teachers and among the parents. A regular assessment of the school climate and support to positive climate was implemented by a team of researchers of The Ohio State University in 2013. Their study was aimed at formulating suggestions for the development of positive climate. But attention was paid also to origination and consequences of negative climate with respect to incidence of bullying at school (Wang, Berry, \& Swearer, 2013). The researchers found that if students feel aversion to school, it is often present also in their parents' minds. Adverse climate influences the life at school inconveniently and may provoke loss of motivation, reluctance to school and learning, bad school results, neuroses and other health problems (Pitha \& Helus, 1993).

\section{Research of school climate}

The research of school climate is described as human-oriented. That expresses that it is oriented on the human in the role of respondent and researcher, but also in the role of climate creator. The history of research of school climate dates back to the 1950s and 1960 s when great attention was paid primarily to conception and verification of research tools (Halpin \& Croft, 1963), while less interest was devoted to theoretical foundations, ascertainment of the climate particularities and solution of climatic problems (Janke, 2006). At the beginning, the first studies of school climate were implemented primarily in the United States; in the 1970s and 1980s, they were common in Germany as well (Fend, 1977; Dreesmann, 1979; Lange et al., 1983). In the Czech Republic, space for research of the school climate was created after 1990 only. The first researchers included Lašek (1991, 1995, 2012), Klusák (1993), Mareš (1998, 2000), Grecmanová (1996, 2008) and others. Later, the research was joined e.g. by Urbánek (2003, 2005, 2008), Ježek (2003, 2004, 2005), Chvál (Urbánek \& Chvál, 2012), Kantorová (2015).

The research of school climate often has a descriptive character of the general school environment or of its part, according to the perception, experience and evaluation of its creators: students, teachers (school direction), parents, etc. Besides the less frequent description or assessment of the general school environment and climate, we can find 
more frequently studies of the climate of the class, of the teaching staff and assessment of partial educational aspects and relations: interpersonal relations of teachers (Urbánek, 2003; Kallestad, 2010; Kottkamp et al., 2012), social structure in class, acceptance of students by ethnic groups (Fellner et al., 1997; Brand et al., 2008), influence of school procedures on social relations among students (Wardová, 1994; Brand et al., 2008; Ding et al., 2011), clarity of rules and order during lessons (Grecmanová, 2004; Brand et al., 2008; Ding et al., 2011; Zullig et al., 2011), etc. The studies of school climate observe and compare for example the differences in the school environment (Cemalcilar, 2010; Zullig et al., 2011), differences in perceptions, by researching the opinions of different respondent groups (teachers $x$ students $x$ parents) on the climate (Hanif \& Smith, 2010). Researchers are interested also in environment factors influencing the climate, including the ways, intensity and circumstances of the influence, as well as the effects of the climate on the factors, etc. (Cemalcilar, 2010; Zullig et al., 2011). Recently, the students' empathy with regard to the school climate was researched. The study showed that empathy has influence on better study results of the students. But the influence of empathy on the climate was considered arguable (Zorza \& Marino, 2015). It can be stated, with respect to the research of school climate, that it may constitute a source of information on many educator phenomena and areas. In brief, it may even show how teachers and students see their life in the school environment (Brand et al., 2008; Ding et al., 2011). According to the results of the study (diagnostic process) of the school climate, the "favourable school" climate will enable further satisfied life in its environment, while pedagogical measures and corrections can be initiated for the welfare of teachers, students and parents if an adverse climate is identified (Mareš, 2005; Benack, 2006; Grecmanová, 2008; Kallestad, 2010).

The research of the school climate should always use at least two groups of respondents (students, teachers, school direction, parents, school inspectors, operation employees, etc.), to have sufficient and objective informative value. Students, but also teachers and parents are most frequently approached as respondents. The first group of respondents students - are primarily focused on the relations they establish among each other, on their relations to the teachers or on their views on the lessons. Students versus school climate were focused by studies made e.g. by Walberg (1966); Moos and Tricket (1974); Fend (1977); Dreesmann (1979, 1981, 1982); Bessoth (1989); Mareš and Lašek (1991); Eder (1996); Satow (2001); Lašek (2001); Linková (2002); Grecmanová (2002); Hanke (2005); Benack (2006); Dopita, Grecmanová and Chráska (2008); Bear et al., (2011); Zullig et al., (2011); Yang et al., (2013); Kantorová (2015). Teachers are the second group of respondents of climate studies, who often assess the social and cultural dimensions of the school environment. The studies of school climate focused on teachers are documented in different authors' publications (Anderson, Walberg, \& Welch, 1969; Thomas, 1976; Fend, 1977; Randhawa \& Michayluk, 1975; Moos, 1979; Průcha, 1997; Urbánek, 2003, 2005; Horvátová, 2005; Janke, 2006; Urbánek \& Chvál, 2012; Grecmanová et al., 2013; Skopalová, 2014; Momma \& Anis-Ul Maque, 2014; etc.). The third group of respondents is represented by parents who are involved in assessing the school climate (Hendson \& Kearney, 2016) usually as indirect 
participants of school life, through mediation of their children. The climate studies with respect to parents were implemented also in the past (Walberg, 1972; Stangl, 1982; Eder, 1996; Grecmanová et al., 1998; Schaffer, unpublished texts; etc.). It is difficult to collect sufficient amount of statements from parents, students and teachers to allow a statement on the general school environment and climate; therefore the studies are often limited only to its variants (class climate, teaching staff climate, etc.), which need not be commented by all respondent groups stated above (teachers, students, parents, school direction), but for example only by students and teachers. The highest level of objectiveness is found in students, when comparing the statements of the individual respondent groups. The teachers and school direction sometimes deviate from reality, trying to show it "in better light" (Grecmanová, 2008).

The research methods are based on quantitative and qualitative research approaches. Quantitative studies are more frequent and they allow better capturing of the school climate through description of perception, experience and assessment of people (also in respondent roles) who belong to and shape the school environment. Questionnaire and sociometric techniques are used. However, quantitative methods also cause some problems in the research of school climate. On one hand, they suggest the climate structure in advance, which sometimes leads to distortion to the phenomenon (Mareš \& Ježek, 2006). The quantification of the findings might not be optimal either. Some climate aspects can be squeezed into figures and data only with difficulty. Qualitative studies rely on observation, interviews, analysis of drawings, documents, photographs, etc. (Hendl, 2006). Some of the above stated methods and approaches (observation, analysis of photographs) do not allow linking the research of the climate with the experience and assessment of the teachers, students and parents, unless they are parallelly researchers. Qualitative studies are more time consuming. But the positive thing is that when processing the results, the descriptive and metaphoric (artistic) language can be used, which often captures the climate better.

The researchers studying the school climate are usually external researchers who have experience with the investigation of the school climate. The benefits of their involvement in the research of the school climate are seen in the researcher's professional preparedness and detached view, focus on the research goal, and lack of involvement in the relations among the school employees. Different questionnaires were developed for their needs in foreign countries, e.g.: the High-School Characteristics Index - Der SekundarschulMerkmals-Index by Stern (1970) is aimed at understanding the students' needs and the school expectations. The same concept, but at the level of teaching, is applied at present in the questionnaire known also in our country: the Classroom-Environment-Scale, CES by Moos (1979). Further, the School Climate Scale (SCS) - by Haynes, Emmons and Comer (1993) is also used.

Examples of selected questionnaire areas: my school is in a safe place; everybody gets the same approach in our school.

My School Inventory (MSI) - Der Fragebogen Meine Schule - by Ellet and Walberg (1979) corresponds, at the class level, with My Classroom Inventory by Anderson 
(1973) with the following dimensions: satisfaction, tension, competence, coherence and demandingness.

Examples of selected questionnaire areas: students in our school are friendly; students compete with each other; some students say that school is funny; some students try to do their work better than others.

Fragebogen für Lehrer, Schüler und Eltern - Questionnaires for teachers, students and parents by Oswald et al. (1989) deal with interactions, feelings and understanding of roles. The interaction patterns concern everybody involved in the education in some way: teacher $x$ students, school direction $x$ teachers, teacher $x$ teacher, teachers $x$ parents, students $x$ students. Feelings of teachers are investigated with regard to their overloading and feelings of students are investigated with regard to their fear of examinations. A more recent questionnaire for verification of interpersonal relations among students is the Gerechtes Schulklima (FAIR-L) - Fair school climate from 2002 by Dalbert and Stöber. Examples of selected questionnaire areas: teachers in our school are fair; teachers in our school call a spade a spade.

At present, the following questionnaires are available too:

Inventory of School Climate - Teacher (ISC-T) by Brand et al. (2008), to investigate relations between teachers and students, empathy among students, rules, disturbing, safety, performance. A similar questionnaire was constructed for the group of student respondents: Inventory of school climate - student (ISC-S) - from 2003 by Brand, Felner and Ahim et al.

Examples of selected questionnaire areas: students strive to get the best marks; there are students looking down on others; students in our school get help with decision making.

Delaware School Climate Survey-Student (DSCS-S) - a questionnaire used in the city of Delaware, by Bear et al. (2011), focused on safety / confidence in school, justice, rules, relations between teachers and students and among students.

Modified - Delaware School Climate Survey-Student (M-DSCS-S) - a modified version of the above stated questionnaire by Yang et al. (2013), focused on relations between teachers and students, relations among students, observance of rules and fair approach, relation to school.

Recently, the research of school climate has included, additionally to the still most widespread questionnaire method (Wang \& Degol, 2016), also the focus group method or interviews (Momma \& Anis-Ul Hague, 2014). Students who were involved in bullying, both as aggressor and as victims, were subject to investigation of subclinical psychotic experience in relation to the school climate. The results were presented based on regressive analysis (Horrevorts, Monshouwer, Wigman, \& Vollenbergh, 2014). The school climate research verifies also theoretical models. The ascertainment of correlations between democratic school climate and civic engagement of teenagers (Lenzi et al, 2014) is an example.

It was expected that some questionnaires will be also used by school employees; that has not been the case at considerable degree yet. It even seems that the teachers refuse 
to implement research of school climate by themselves due to lack of time, lack of confidence in their research abilities, fear of misuse of the results, etc. In view of that and of the belief that the research of school climate should serve primarily to the teachers, students, parents and school direction, the following questionnaires were developed: School climate. A set of questionnaires for teachers, students and parents (Grecmanová et al., 2012), School climate. A set of questionnaires for teachers, students and parents. 1st revised version (Mareš et al., 2012). School class climate. Questionnaire for students (Mareš \& Ježek, 2012). The above stated research tools include manuals with instructions for everybody who will implement research with the questionnaires.

The questionnaire for students, developed by Grecmanová et al. (Grecmanová et al., 2012), includes for example the following items: I have a classmate to whom I can confide everything; I can rely on all classmates; me and my classmates respect each other; everybody can admit one's mistake before the classmates; I am afraid of some classmates.

The set of questionnaires developed by Mareš et al. (Mareš et al., 2012), aimed at verifying the relations among students, includes for example the following items: I have a classmate to whom I can confide everything; I can rely on all classmates; me and my classmates respect each other; everybody can admit one's mistake before the classmates; I am afraid of some classmates.

Finally, some examples of items from the questionnaires for students by Mareš and Ježek (Mareš \& Ježek, 2012) can be mentioned: I have many good friends in my class; my classmates treat me friendly; when we get a common task, I feel good cooperating with my classmates; I feel most of my classmates like me; when I need, my classmates help me.

All above stated item examples are specific by focus on relations among students.

The conclusion of the theoretic part of the article is devoted to the goal of the study: to describe the relations among students at selected elementary schools from the perspective of students, parents and teachers.

\section{Study at senior elementary school}

The study had three partial stages. First the questionnaires were developed. Then the questionnaire research followed, and the last part described the school climate of selected senior elementary schools $\left(6^{\text {th }}-9\right.$ th year).

\section{Description of questionnaires and their focuses}

The study made use of a set of questionnaires. The set included three questionnaires - for parents, for teachers and for students. When constructing the questionnaires, experience from construction and verification of other questionnaires was used (Grecmanová, 2008; Grecmanová et al., 2013, Dopita, Grecmanová \& Chráska, 2008). The contents of the three questionnaires was focused on social, and cultural dimension of school 
environment. The following relations were observed: students-students, teachersstudents, teachers-teachers, teachers-director, students-parents, parents-teachers with respect to their actions at school. Phenomena like friendship, conflicts, aggression, fear, understanding, support, help, confidence, cooperation, interest, communication, respect to teacher, "usefulness" of knowledge, personal assertion, evaluation, individual approach, teaching procedures, rules, keeping the word, director's track of school, school equipment, satisfaction with school, etc. came to the foreground. The questionnaire was constructed by one of the co-authors ${ }^{2}$ of the article for the purpose of the above stated project. It is an own questionnaire, not an adapted questionnaire.

The questionnaire for parents was the shortest, containing thirteen close-ended statements and three open-ended questions. The questionnaire for teachers contained twenty-five close-ended statements and three open-ended questions. The questionnaire for students also had 25 close-ended statements and only one open-ended question. The statements were formulated concisely and clearly, trying to express one fact or to follow only one phenomenon at a time. All statements were expressed in a positive manner, to avoid confusing the respondents when "disagreeing" with negations. The items served to ascertain data (facts, opinions, attitudes) needed to meet the research intention. The close-ended statements were evaluated at a dichotomic scale with the following options to choose: "I agree" or "I disagree". This way of evaluation of statements was chosen for better understandability for the respondents, particularly for the students, for faster (more time-efficient) evaluation of the statements, but also because of the need to choose one of the extreme values offered. The danger of black and white perspective was eliminated by the possibility to compare the evaluation of statements from different respondent groups. The respondents were informed in written about the way of evaluation at the beginning of each questionnaire.

\section{Research implementation}

The research was implemented at four complete elementary schools in the Czech Republic (ZŠ III is a special school) interested in cooperating and in researching the school climate. Originally, the study was intended to include all classes of the elementary schools, but in view of the selected questionnaire method, it was decided to focus only on the senior elementary school. The answers were statistically evaluated in the first and second data classification. The subsequent statistical data processing, i.e. the combination of individual features made use of the Chi-squared test ( ) with 0.05 level of significance, as well as Pearson's correlation coefficient, as the data were nominal. In this context, it was researched whether the frequencies acquired by measurement in school reality differ from the theoretical frequencies corresponding to zero hypothesis (Chráska, 2007). Pearson's correlation coefficient helped to determine the closeness of relation between the phenomena compared (Chráska, 2007).

\footnotetext{
2 Prof. PhDr. Helena Grecmanová, Ph.D.
} 


\section{Relations among students in individual elementary schools from the perspective of students, teachers and parents}

The researchers paid attention to the evaluation of whether the student has a classmate to whom he/she can confide (item No. 5), whether the student has good relations with the classmates (item No. 6) and is not afraid of them (item No. 7), whether the student has friends among the classmates (item No. 12), whether the classmates support each other (item No. 13) and whether the classmates do not harm each other during breaks (item No. 19), as perceived by the students. The teachers assessed mutual help among students (item No. 22) and occurrence of aggression among students at school (item No. 23). The parents commented the child's fear of classmates (item No. 4), whether the child has friends at school (item No. 5) and whether the child has contacts with classmates after school (item No. 7).

The subsequent test first states the results of the first classification of opinions of the students, teachers and parents. The results of the second classification are referred only in statistically significant cases, only from the students' perspective.

\section{Elementary school I.}

Characteristics of the school and of the research set:

201 (of 201) students, 24 (of 24) teachers, 79 (of 201) parents.

The relations among students were characterized relatively positively by the students. Nearly all students stated to have friends among classmates (99\%), to have good relations with classmates (95\%) and to have a classmate to whom they can confide $(91.5 \%)$. Three quarters of respondents of ZŠ I., i.e. $74.2 \%$ agree with mutual support of classmates. Less than a quarter of classmates $(22.1 \%$ ) have experienced mutual harming during breaks. It is satisfying that up to $92.5 \%$ students are not afraid of their classmates. The teachers evaluated the relations among students almost in two thirds as showing signs of aggression (59.1\%); however, the students help each other, according to the teachers' statements $(90 \%)$. The parents stated that the children are not afraid of classmates, which was agreed by $94.9 \%$, and that they have friends at school (agreed by $100 \%$ ). The child has contacts with classmates also after school (89.7\%).

The correlations of items in the STUDENTS questionnaire (important items 5, 6, 7, 12, 13, 19) are always stated in subsequent tables (Table 1, 2, 3, 4). ${ }^{3}$

\footnotetext{
3 The tables state the calculated values of Pearson's correlation coefficient, always for specific item combinations in the questionnaire. The questionnaires are enclosed to the article. The values in bold show dependence between the phenomena observed.
} 
Table 1 Correlation of items - Elementary school I.

\begin{tabular}{|r|c|c|c|c|c|c|}
\hline & $\mathbf{5}$ & $\mathbf{6}$ & $\mathbf{7}$ & $\mathbf{1 2}$ & $\mathbf{1 3}$ & 19 \\
\hline $\mathbf{5}$ & $\mathrm{X}$ & $\mathbf{0 . 1 7}$ & $\mathbf{0 . 1 2}$ & & & \\
\hline $\mathbf{6}$ & & $X$ & 0.02 & & & \\
\hline $\mathbf{7}$ & & & $X$ & & & \\
\hline $\mathbf{1 2}$ & & & & $X$ & $\mathbf{0 . 1 7}$ & \\
\hline $\mathbf{1 3}$ & & & & & $X$ & \\
\hline 19 & & 0.01 & $\mathbf{0 . 1 7}$ & 0.05 & 0.12 & $\mathrm{X}$ \\
\hline
\end{tabular}

Source: own processing

Pearson's correlation coefficient shows only a weak dependence between items 5 and 6, 7 and 19, 12 and 13. Students have good relations with classmates and they have classmates to whom they can confide. Classmates are not afraid of each other, they do not harm each other during breaks. They have friends among classmates and support each other.

\section{Elementary school II.}

Characteristics of the school and of the research set:

469 (of 469) students, 32 (of 32) teachers, 316 (of 469) parents.

In this elementary school, the students have friends among classmates in $94.9 \%$; they have good relations with classmates $(91.4 \%)$; many of them also have a classmate to whom they can confide. $83.4 \%$ students can count on mutual support among students. Some classmates $(23.5 \%$ ) have experienced mutual harming among classmates during breaks, but $88.1 \%$ are not afraid of their classmates. When the teachers assessed the relations among students, it was found out that they see aggression at school very often (93.1\%). But many students ( $80 \%$ ) help each other. The parents stated that the children are not afraid of classmates in $90.2 \%$ and that they have friends at school $97.8 \%$. The child has contacts with classmates also after school (84.9\%). 
Table 2 Correlation of items - Elementary school II.

\begin{tabular}{|r|c|c|c|c|c|c|}
\hline & $\mathbf{5}$ & $\mathbf{6}$ & $\mathbf{7}$ & 12 & 13 & 19 \\
\hline $\mathbf{5}$ & $\mathrm{X}$ & 0.30 & 0.13 & & & \\
\hline $\mathbf{6}$ & & $X$ & 0.2 & & & \\
\hline $\mathbf{7}$ & & & $X$ & & & \\
\hline 12 & & & & $X$ & 0.24 & \\
\hline 13 & & & & & $X$ & \\
\hline 19 & & 0.17 & 0.32 & 0.10 & 0.23 & $X$ \\
\hline
\end{tabular}

Source: own processing

As for ZŠ II, Pearson's correlation coefficient shows more frequent dependence between the phenomena under research; it also achieves higher values than at Ž́ I. But it is still a low dependence, specifically between items 5 and 6 (the student has a classmate to whom he/she can confide, and the student has good relations with classmates), and between items 7 and 19 (the student is not afraid of classmates and classmates do not harm each other during breaks). There is only a weak dependence between items 6 and 7,13 and 12,19 and 6 .

\section{Elementary school III.}

Characteristics of the school and of the research set:

42 (of 42) students, 10 (of 10) teachers, 20 (of 42) parents.

The students stated to have friends among classmates ( $90.5 \%$ ), to have good relations with classmates $(97.6 \%)$ and some of them stated to have a classmate to whom they can confide (69.1\%). $73.8 \%$ students have experienced mutual support among students. Up to $28.6 \%$ students reported mutual harming of classmates during breaks. In spite of that, $80.5 \%$ students are not afraid of their classmates. Teachers confirmed frequent aggression in relations among students in $81.8 \%$. However, some students $(77.8 \%)$ help each other. The statement that the children are not afraid of their classmates was agreed by $80.8 \%$ parents; $96.7 \%$ of them stated that their children has friends at school. According to the parents, the child has contacts with classmates also after school (78\%). 
Table 3 Correlation of items - Elementary school III.

\begin{tabular}{|r|c|c|c|c|c|c|}
\hline & 5 & 6 & 7 & 12 & 13 & 19 \\
\hline 5 & $X$ & 0.23 & 0.19 & & & \\
\hline $\mathbf{6}$ & & $X$ & 0.31 & & & \\
\hline 12 & & & $X$ & & & \\
\hline 13 & & & & $X$ & 0.34 & \\
\hline 19 & & & & & $X$ & \\
\hline & & 0.24 & 0.09 & 0.32 & 0.32 & $X$ \\
\hline
\end{tabular}

Source: own processing

Pearson's correlation coefficient shows only a weak dependence between items 5 and 6, 5 and 7, 19 and 6. There is low dependence between items 6 and 7 (the student has good relations with classmates and is not afraid of them), 12 and 13 (the student has friends among classmates and the classmates support each other), 12 and 19 (the student has friends among classmates and the classmates do not harm each other during breaks), and 13 and 19 (the classmates support each other and they do not harm each other during breaks).

\section{Elementary school IV.}

Characteristics of the school and of the research set:

177 (of 177) students, 13 (of 13) teachers, 122 (of 177) parents.

The students confirmed to have friends among classmates in $91.3 \%$, to have good relations with classmates in $90.9 \%$ and to have a classmate to whom they can confide in $82.5 \%$. Mutual support among classmates is common to $75.1 \%$ students; $26.6 \%$ students have seen mutual harming among classmates during breaks; however, $90.4 \%$ students are not afraid of their classmates. Teachers reported $100 \%$ occurrence of aggression among classmates. However, students also help each other (90\%). The child has contacts with classmates also after school only in $45 \%$. At ZŠ IV., only $65 \%$ parents stated that the children are not afraid of their classmates, but that they have friends at school (100\%). 
Table 4 Correlation of items - Elementary school IV.

\begin{tabular}{|r|c|c|c|c|c|c|}
\hline & $\mathbf{5}$ & $\mathbf{6}$ & $\mathbf{7}$ & $\mathbf{1 2}$ & $\mathbf{1 3}$ & $\mathbf{1 9}$ \\
\hline $\mathbf{5}$ & $\mathrm{X}$ & 0.11 & 0.15 & & & \\
\hline $\mathbf{6}$ & & $\mathrm{X}$ & 0.03 & & & \\
\hline $\mathbf{7}$ & & & $X$ & & & \\
\hline $\mathbf{1 2}$ & & & & $X$ & $\mathbf{0 . 2 1}$ & \\
\hline $\mathbf{1 3}$ & & & & & $X$ & \\
\hline $\mathbf{1 9}$ & & 0.00 & $\mathbf{0 . 1 9}$ & 0.06 & 0.11 & $X$ \\
\hline
\end{tabular}

Source: own processing

Pearson's correlation coefficient also revealed only weak dependences between items 12 and 13 (the student has friends among classmates; the classmates support each other) and 7 and 19 (the student is not afraid of the classmates and there is no harming among classmates during breaks). Nevertheless, we do not see a weak dependence as insignificant in the area of relations.

\section{Conclusion}

The authors have been researching the school climate since several years; they consider it a significant school environment phenomenon, experienced, assessed and evaluated by the creators of the environment, primarily by students, teachers and parents. Many studies have shown that additionally to the cultural dimension of school environment, primarily the social dimension is a very important area affecting the school climate (Grecmanová, 2008). Social dimension is a relationship dimension concerning communication and cooperation, behaviours among students, teachers and parents. Therefore this article focused on the school climate, on research approaches to school climate and on current research of climate in four selected elementary schools in the Czech Republic from the perspective of relations among students, as assessed by students, teachers and parents. The specific focus on the relations among students was undoubtedly provoked by the increase of risky behaviour of students at schools that must be address or rather prevented by the teachers. It cannot be expected that positive climate will develop at schools where aggression, bullying and truancy occurs.

All schools subject to the study brought a very frequent statement that the students have friends among classmates, that they have good relations with classmates and, except for ZŠ III., that they have also a classmate to whom they can confide. Mutual support among classmates was shown in about three fourth of cases. However, about one fourth of students has experienced harming among classmates during breaks, although most pupils are not afraid of their classmates. Aggression among pupils was confirmed also by 
teachers, mostly at ZŠ IV. (100\% occurrence where fear of classmates was mentioned even by parents (35\%). It is certainly difficult to assess relations among pupils and the climate in the said schools without further research in more detail. Therefore we consider simple description as most adequate. Pearson's correlation coefficient revealed only weak or low dependences among the phenomena under research at all schools; that, however, does not mean that the dependences are insignificant. It can be stated with some caution that if the described situations occur at school, they often exist independently of each other. The finding can have a significance in case of searching causes of the specific character of a climate and in case of striving to change and shape it.

\section{References}

Anderson, G. J. (1973). The assessment of learning environments: A manual for the Learning Environment Inventory and the My Class Inventory. Halifax: Atlantic Institute of Education.

Bear, G. G. et al. (2011). Delaware School Climate Survey - Student: Its factor structure, concurrentvalidity, and reliability. Journal of School Psychology, 49(2), 157-174.

Bennack, J. (2006). Erziehungskonzepte in der Schule. Praxishilfen für den Umgang mit Schülerinen und Schülern. Weinheim und Basel: Beltz.

Bessoth, R. (1989). Organisationsklima an Schulen. Neuwied: Luchterhand.

Brand, S. et al. (2008). A large scale study of the assessment of the social environment of middle and secondary school: The validity and utility of teachers' rating of school climate, cultural pluralism, and safety problems for understanding school effects and school improvement. Journal of School psychology, 46(5), 507-535.

Cassinerio, CH., \& Lane-Garon, P. S. (2006). Changing school climate one mediator at a time: Year-one analysis of a schoolbased mediation program. Conflict Resolution Quartely, 23(4), 447-460.

Cemalcilar, Z. (2010). Schools as socialisation context: Understanding the impact of school climate factors on students'sense of school belonging. Journal of Applied Social Psychology, 59(2), 243-272.

Chráska, M. (2007). Metody pedagogického výzkumu. [Methods of Pedagogical Research]. Prague: Grada.

Cohen, J. et al. (2009). School climate: Research, policy, practice and teacher education. Teacher College Record, 111(1), 180-213.

Ding, C., Liu, Y., \& Berkowitz, M. (2011). The study of factor structure and reliabity of an abbreviated school climate survey. Canadian Journal of School Psychology, 26(3), 241-256. 
Dopita, M., Grecmanová, H., \& Chráska, M. (2008). Zájem žáků středních škol o fyziku, chemii a matematiku. [Interest of Secondary School Students in Physics, Chemistry and Math]. Olomouc: Palacký University in Olomouc.

Dreesmann, H. (1981). Zur Beziehung zwischen Rechenleistung, kognitiven Variablen und Unterrichtsklima. Zeitschrift für Empirische Pädagogik.

Dreesmann, H. (1982). Unterrichtsklima. Weinheim: Beltz.

Eder, F. (1996). Schul- und Klassenklima. Ausprägung, Determinanten und Wirkungen des Klimas an höheren Schulen. Insbruck: Studien Verlag.

Ellet, Ch. D., \& Walberg, H. J. (1979). Principals competency, environment and outcomes. In H. J. Walberg (Ed.), Educational environments and effects: Evaluation, policy and productivity (pp. 140-164). Berkely: McCutchan.

Fellner, R. et al. (1997). The impact of school reform for the middle grades: A longitudinal study of a network engaged in turning points-based comprehensive school transformation. In R. Takanischi, \& D. Hamburg (Eds.), Preparing adolescents for the twenty-first century: Challenges facing Europe and the United States (pp. 38-69). New York: Sage Press.

Fend, H. (1977). Schulklima: Soziale Einfl ussprozesse in der Schule. Weinheim: Beltz.

Fend, H. (1988). Sozialgeschichte des Aufwachsens. Frankurt: Suhrkamp.

Fischer, B. (2003). Soziales Lernen an einer Reformschule. Evaluationsstudie über Unterschiede von Sozialisatuonsprozessen in Reform- und Regelschulen. Weinheim, München: Juventa.

Gavora, P., \& Braunová, J. (2010). Adaptácia Dotazníka organizačnej klímy školy (OCDQRS). [Adaptation of Questionnaire of Organizational Climate of School (OCDQ-RS]. Pedagogická orientace [Pedagogical Orientation], 20(1), 39-59.

Grecmanová, H. (1996). Školní klima v podmínkách transformace školské soustavy. [School Climate in Conditions of Transformation of School System]. Dissertation Thesis. Olomouc: Faculty of Education of Palacký University in Olomouc.

Grecmanová, H. (2002). Evaluace vyučovacího klimatu. [Evaluation of Climate of Teaching]. E-Pedagogium, 4, 13-48.

Grecmanová, H. (2008). Klima školy. [Climate of School]. Olomouc: Hanex.

Grecmanová, H., Dopita, M., Kantorová, J., Skopalová, J., \& Chvál, M. (2013). Organizační klima fakult pripravujících učitele. [Organizational Climate of Faculties Preparing Teachers]. Olomouc: Faculty of Education, Palacký University in Olomouc. 
Grecmanová, H., Dopita, M., Poláchová Vaštatková, J., \& Skopalová, J. (2012). Klima školy. Soubor dotazníkủ pro učitele, žáky a rodiče. [Climate of the school. A set of questionnaires for teachers, pupils and parents]. Prague: Národní ústav pro vzdělávání [National Institute for Education].

Grecmanová, H., Geršicová, Z., \& Muchacka, B. (2012). Učitel a jeho vnímanie prostredia školy a triedy. [Teacher and his/her Perceptions of School Environment and Class]. Bratislava: OZ V4.

Haertel, G. D., Walberg, H. J., \& Haertel, E. H. (1981). Socio-psychological environments and learning: A quantitative synthesis. British Educational Research Journal, 7(1), 27-36.

Halpin, A. W., \& Croft, D. B. (1963). The organizational climate of schools. Chicago: University of Chicago.

Hanke, O. (2005). Erziehen: Handlungsrezepte für den Schulalltag in der Sekundarstufe. Die Kraft der Klasse fördern. Berlin: Cornelsen.

Hannif, R., \& Smith, P. K. (2010). Development of school social climate scale. Unit for School and Family Studies. Goldsmith: University of London.

Hendl, J. (2006). Kvalitativní výzkum v pedagogice. [Qualitative Research in Pedagogy]. In Současné metodologické prístupy a strategie pedagogického výzkumu. [Current Methodological Approaches and Strategies of Pedagogical Research]. Pilsen: University of West Bohemia. [CD-ROM].

Hendron, M., \& Kearney, Ch. (2016). School Climate and Student Absenteeism and Internalizing and Externalizing Behavioral Problems. Children \& Schools, 38(2), 109-116.

Hopson, M. L., Schiller, S. S., \& Lawson, H. A. (2014). Exploring Linkages between School Climate, Behavioral Norms, Social Supports, and Academic Success. Social Work Research, 38, 197-209.

Horrevorts, E. M. B., Monshouwer, K., Wigman, J. T. W., \& Vollenbergh, W. A. M. (2014). Relation between bullying and subclinical psychotic experiences and the influence of the bully climate of school classes. Eur Child Adolesc Psychiatry, 23, 765-772.

Horváthová, K. (2005). Klíma školy [School Climate]. Pedagogická orientace [Pedagogical Orientation], 1, 37-45.

Hosford, S., \& O'Sullivan, S. (2016). A climate for self-efficacy: the relationship between school climate and teacher efficacy for inclusion. International Journal of Inclusive Education, 6(20), 604-621. 
Janke, N. (2006). Soziales Klima an Schulen aus Lehrer-, Schulleiter- und Schülerperspektive. Eine Sekundäranalyse der Studie "Kompetenzen und Einstellungen von Schülerinen und Schülern - Jahrgangsstufe 4 (KESS 4)". Münster: Waxmann.

Ježek, S. (2003). Možnosti konceptualizace školního klimatu. [Possibilities of Conceptualization of School Climate]. In Ježek, S. (Ed.), Psychosociální klima školy I. [Psycho-social Climate of School I.] (pp. 2-31). Brno: MSD.

Ježek, S. (2004). Psychosociální klima školy II. [Psycho-social Climate of School II.]. Brno: MSD. Ježek, S. (2005). Psychosociální klima školy III. [Psycho-social Climate of School III.]. Brno: MSD. Kallestad, J. H. (2010). Changes in school climate in a long-term perspective. Scandinavien Journal of Research, 54(1), 1-14.

Kantorová, J. (2015). Školní klima na školách poskytujicích střední vzdělání s výučním listem. [School Climate in Schools Providing Secondary Education with an Apprenticeship Certificate]. Olomouc: Faculty of Education, Palacký University in Olomouc.

Klusák, M. (1993). Vědět jak zacházet s klimatem ve třídě. [Know how to deal with the climate in the classroom]. In Pedagogický výzkum a transformace české školy. [Pedagogical Research and Transformation of the Czech School] (pp. 62-67). Prague: ČAPV and Faculty of Education of Charles University.

Lange, B., Kuffner, H., \& Schwarzer, R. (1983). Schulangst und Schulverdrossenheit. Eine Längsschnittanalyse von schulischen Sozialisationseffekten. Oplader: Westdeutscher Verlag.

Lašek, J. (1994). Prvé skúsenosti s meraním klímy ve škole a v učitelskom sbore. Pedagogická revue, 47(1-2), 43-50.

Lašek, J. (2001). Sociálně psychologickéklima školních tříd a školy. [Socially Psychocological Climate of Classes and School]. Hradec Králové: Gaudeamus.

Lašek, J. (2012). Sociálně psychologické klima školních tříd. [Socially Psychocological Climate of Classes]. Hradec Králové: Gaudeamus.

Lašek, J., \& Mareš, J. (1991). Jak změřit sociální klima tř́ídy? [How to Measure Social Climate of Class]. Pedagogická revue,43(6), 401-410.

Lenzi, M. et al. (2014). How School Can Teach Civic Engagement Besides Civic Education: The Role of Democratic School Climate. American Journal of Community Psychology, 54(3/4), 251-261.

Linková, M. (2002). Preferované klima školní třídy a některé jeho determinanty. In Výzkum školy a učitele: sborník př́spěvků z X. konference ČAPV [Research of School and Teacher: proceedings from $10^{\text {th }}$ conference ČAPV] (p.44). Prague: Faculty of Education, Charles University in Prague. 
Mareš, J. (1998). Sociální klima školní třídy. [Social Climate of Class]. Prague: Institut pedagogicko-psychologického poradenství [Institute for Pedagogical and Psychological Consulting].

Mareš, J. (2000). Sociální klima školy. [Social Climate of School]. Pedagogická revue [Pedagogical Revue], 52(3), 241-254.

Mareš, J. (2003). Diagnostika sociálního klimatu školy. [Diagnostics of Social Climate of School]. In S. Ježek (Ed.), Sociální klima školy I [Social Climate of School I] (pp. 32-74). Brno: MSD, Ltd.

Mareš, J., \& Ježek, S. (2006a). Kvalitativní metody pro diagnostiku psychosociálního klimatu školy. [Qualitative Methods for Diagnostics of Psycho-social Climate of School], $1^{\text {st }}$ part. Pedagogická revue [Pedagogical Revue], 58(1), 30-45.

Mareš, J., \& Ježek, S. (2006b). Kvalitativní metody pro diagnostiku psychosociálního klimatu školy. [Qualitative Methods for Diagnostics of Psycho-social Climate of School] $2^{\text {nd }}$ part. Pedagogická revue [Pedagogical Revue], 58(2), 127-141.

Mareš, J., \& Lašek, J. (1990/1991). Známe sociální klima ve výuce? [Do we Know Social Climate in Education]. Výchova a vzdělávání [Education and Teaching],1(4), 173-176.

Mareš, J., \& Lašek, J. (1996). Sociálně psychologické klima třídy. In Pedagogika I. [Pedagogy I.] (pp. 97-110). Ostrava: Faculty of Education of University of Ostrava.

Mareš, J., Ježek. S., Grecmanová, H., \& Dopita, M. (2012). Klima školy. Soubor dotazníků pro učitele, žáky a rodiče. [School Climate. Compilation of Questionnairies for Teachers, Pupils and Parents]. $1^{\text {st }}$ revised edition. Prague: Národní ústav pro vzdělávání [National Institute for Education].

Mareš, J., Průcha, J., \& Walterová, E. (2003). Pedagogický slovník. [Pedagogical Dictionary]. Prague: Portál.

Miovský, M. et al. (2015). Prevence rizikového chování. [Risk Behaviour Prevention] Prague: First Faculty of Medicine, Charles University in Prague.

Momna, A., \& Anis-Ul-Haque, M. (2014). Development of School Climate Scale (SCS): Measuring. Journal of Social Sciences, 2(8), 51-58.

Moos, R. H. (1979). Evaluating educational environments. Procedures, measures, findings and policy implications. San Francisco: Jossey Bass.

Moos, R. H., \& Tricket, Edison J. (1974). Classroom environment scale manual. Palo Alto: Consulting Psychologists Press.

Oswald, F. et al. (1989). Schulklima. Die Wirkungen der persönlichen Beziehungen in der Schule. Wien: Universitätverlag. 
Petlák, E. (2006). Klíma školy a klíma triedy. Bratislava: IRIS.

Pithha, P., \& Helus, Z. (1993). Návrh pojetí obecné školy. [Draft Concept of General School]. Prague: Portál.

Popa, N. L. (2012). Percepcions of school climate among children of Romania migrants. Procedia - Social and Behavioral Sciences, 33, 119-123.

Průcha, J. (2005). Česká pedagogická věda v současnosti: Pokus o pozitivní reflexi stavu. [Contemporary Czech Pedagogical Science: Attempt to Positive Reflection of State]. Pedagogika [Pedagogy], LV(3), 230-247.

Randhawa, B. S., \& Michayluk, J. O. (1975). Learning environment in rural and urban classrooms. American Educational Research Journal, 12(3), 265-279.

Rosolová, M., \& Střelec, S. (2003). Klima na střední škole v retrospektivním pohledu studentů učitelství. [Climate at Secondary School from Retrospective Point of View of Students of Teacher Training]. In M. Chráska, D. Tomanová, \& D. Holoušová (Eds.), Klima současné české školy. [Contemporary Czech School Climate] (pp. 328-335). Brno: Konvoj.

Satow, L. (2001). Immer ein prima Unterrichtsklima? Unterrichten/Erziehen.

Seebauer, R. (2005). Školská a triedna klíma: rakúsky pohl'ad. [School and Class Climate: Austrian Point of View]. Pedagogická revue [Pedagogical Revue], 57(4), 349-361.

Schaffer, F. (unpublished texts). Die "gute Schule" - was ist das?

Skopalová, J., \& Grecmanová, H. (2014). Klima třídy na 2. stupni základních škol z hlediska projevů rizikového chování ve třídě. [Climate of Class in the $2^{\text {nd }}$ Grade of Elementary School from Point of View of Risky Behaviour in Class]. In Pedagogický výzkum: spojnice mezi teorií a praxí. [Pedagogical Research: Link between Theory and Practice]. Olomouc: Agentura Gevak s.r.o. [Gevak Agency Ltd.].

Stern, G. G. (1970). People in context. Measuring person-environment congruence in education and indrustry. New York: John Wiley.

Thomas, A. R. (1976). The organizational climate of schools. International Review of Education, 22, 441-456.

Urbánek, P. (2003). K metodologickým otázkám měření klimatu učitelských sborů. [To Methodological Questions of Measurement of Climate of Teaching Staff]. In S. Ježek (Ed.), Psychosociální klima školy I. [Psycho-social School Climate I.](pp. 123-134). Brno: MSD.

Urbánek, P. (2005). Vliv velikosti školy na klima učitelského sboru. [Influence of Size of School on Climate of Teaching Staff]. In J. Vaštatková (Ed.), Pedagogický výzkum: reflexe společenských potřeb a očekávání? [Pedagogical Research: Reflection of Social Needs and Expectations]. Olomouc: Palacký University in Olomouc. 
Urbánek, P., \& Chvál, M. (2012). Klima učitelského sboru. Dotazník pro učitele. [Climate of Teaching Staff. Questionnaire for Teachers]. Prague: Národní ústav pro vzdělávání [National Educational Institute].

Wang, C., Berry, S., \& Swearer, M. (2013). The Critical Role of School Climate in Effective Bullying Prevention. Theory into Practice, 52(4), 296-302.

Wang, M., \& Degol, J. L. (2016). School Climate: a Review of the Construct, Measurement, and Impact on Student Outcomes. Educational Psychology Review, 28(2), 315-352.

Wardová, M. A. (1994). Učitelovo meranie klímy vo vlastnej triede. [Teacher's Measurement of Climate in Own Class]. Pedagogická revue [Pedagogical Revue], XLVI(9-10), 460-468.

Welch, W. W. (1979). Curriculum and longitudinal effects on learning environment. In H. J. Walberg (Ed.), Educational Environment and Effects (pp. 167-179), Berkeley Calif.: McCutchan.

Yang, Ch. et al. (2013). Students'perceptions of school climate in the U.S. and China. School psychology Quarterly, 28(1), 7-24.

Zorza, J., \& Marino, J. (2015). The influence of effortful control and empathy on perception of school climate. European Journal of Psychology of Education, 30(4), 457-472.

Zullig, K. J. et al. (2011). Relationships among school climate domains and school satisfaction. Psychology in the Schools, 48(2), 133-145.

\section{Authors}

prof. PhDr. Helena Grecmanová, Ph.D.

Faculty of Arts, Palacký University Olomouc

The Department of Sociology, Andragogy and Cultural Anthropology

tr. Svobody 26, 779 00, Olomouc, The Czech Republic

helena.grecmanova@upol.cz

Mgr. Lucie Blaštíková

Faculty of Education, Palacký University Olomouc

The Institute of Education and Social Studies

Žižkovo nám. 5, 771 40, Olomouc, The Czech Republic

lucka.blastikova@seznam.cz 


\section{APPENDIX 1 - QUESTIONNAIRE FOR PUPILS}

Dear pupils,

We would like to ask for cooperation in determining the climate of your school.

We kindly ask you to fill out the following questionnaire. The survey takes only a few minutes. The questionnaire is anonymous, so we ask for true answers.

Please fill in the heading before you start working on the questionnaire.

In the questionnaire, answer like I agree/ I disagree. Please circle the corresponding answer. If you correct your original response, simply cross it out and circle the second option.

Thank you for your willingness.

Have a nice day, a team of authors

\section{SCHOOL:}

CLASS:

BOY

GIRL

\begin{tabular}{|c|c|c|c|}
\hline NUMBER & FORMULATION OF STATEMENT & \multicolumn{2}{|c|}{ ANSWER } \\
\hline 1. & Teachers have understanding for my problems. & I AGREE & I DISAGREE \\
\hline 2. & Teachers keep promises. & I AGREE & I DISAGREE \\
\hline 3. & My parents are interested in my school results. & I AGREE & I DISAGREE \\
\hline 4. & My parents go to class meetings. & I AGREE & I DISAGREE \\
\hline 5. & At school, I have a classmate I can trust. & I AGREE & I DISAGREE \\
\hline 6. & We are friends with classmates. & I AGREE & I DISAGREE \\
\hline 7. & I am not afraid of classmates. & I AGREE & I DISAGREE \\
\hline 8. & At school, I have a teacher I can trust. & I AGREE & I DISAGREE \\
\hline 9. & I am not afraid of teachers. & I AGREE & I DISAGREE \\
\hline 10. & Teachers talk with us about our problems. & I AGREE & I DISAGREE \\
\hline 11. & Teachers are interested in pupils' hobbies. & I AGREE & I DISAGREE \\
\hline 12. & I have friends among classmates. & I AGREE & I DISAGREE \\
\hline 13. & My classmates and I support each other. & I AGREE & I DISAGREE \\
\hline 14. & At school, we follow the rules. & I AGREE & I DISAGREE \\
\hline 15. & I like learning. & I AGREE & I DISAGREE \\
\hline
\end{tabular}




\begin{tabular}{|c|l|c|c|}
\hline $\mathbf{1 6 .}$ & Our teachers teach in interesting way. & I AGREE & I DISAGREE \\
\hline $\mathbf{1 7 .}$ & At school, we pay attention to the lessons. & I AGREE & I DISAGREE \\
\hline $\mathbf{1 8 .}$ & We do not disturb during lessons. & I AGREE & I DISAGREE \\
\hline $\mathbf{1 9 .}$ & During breaks, my classmates and I do not hurt each other. & I AGREE & I DISAGREE \\
\hline $\mathbf{2 0 .}$ & Our teachers praise us. & I AGREE & I DISAGREE \\
\hline $\mathbf{2 1 .}$ & We can improve bad grades (assessments). & I AGREE & I DISAGREE \\
\hline $\mathbf{2 2 .}$ & The principal comes to our class sometimes too. & I AGREE & I DISAGREE \\
\hline $\mathbf{2 3 .}$ & I find our school interesting. & I AGREE & I DISAGREE \\
\hline $\mathbf{2 4 .}$ & The school is well equipped. & I AGREE & I DISAGREE \\
\hline $\mathbf{2 5 .}$ & I am contented at school. & I AGREE & I DISAGREE \\
\hline
\end{tabular}

Do you have any other comments? 